\title{
Pengaruh Efikasi Diri dan Gender Equality Terhadap Motivasi: Study Ex Post Facto Terhadap Guru SMA Swasta di Kabupaten OKU Timur Kota Palembang
}

\author{
Ulfa Adilla \\ Institut Agama Islam Yasni Bungo \\ Email: Adillahasan@gmail.com \\ Muzakki \\ Institut Agama Islam Yasni Bungo \\ Email: muzakki@iaiyasnibungo.ac.id
}

\begin{abstract}
This research objective is to know and analyze the effect of self efficacy and gender equality toward the motivation. The method used in this research is ex post facto with 2x2 factorial design. Research data for this thesis were collected through questionnaire that involved 150 teachers in private senior high school at East Oku Timur-Palembang as respondents. Then the conclusion of this research are: 1) Overall, the teachers's motivation is different between they who have high and low self-efficacy. (2) Overall, the motivation of teachers are different between male and female teachers (3) The male teachers motivation is different between they who have high and low self-efficacy. (4) Female teachers have stronger motivation when they have high self-efficacy, and having weak motivation when their self efficacy is low. (5) There are an interaction effect between self-efficacy and gender equality on the teacher's motivation.
\end{abstract}

Keywords: Self Efficacy, Gender Equality, Motivation, Ex Post Facto.

\begin{abstract}
Abstrak
Tujuan penelitian ini adalah untuk mengetahui dan mengalisis pengaruh efikasi diri dan gender equality terhadap motivasi. Metode yang digunakan dalam penelitian ini adalah ex post facto dengan desain factorial $2 \times 2$. Data penelitian untuk tesis ini dikumpulkan melalui kuisioner dengan melibatkan 150 guru di sekolah menengah swasta di oku timur Palembang sebagai responden. Maka kesimpulan dari penelitian ini adalah: 1) Secara keseluruhan, motivasi guru berbeda bila memiliki efikasi diri tinggi dengan guru yang memiliki efikasi diri rendah. 2) Secara keseluruhan, motivasi guru berbeda antara guru pria dan guru wanita. 3) Bagi guru pria, motivasi guru berbeda antara yang memiliki efikasi diri tinggi dengan yang memiliki efikasi diri rendah. 4) Bagi guru wanita, motivasi guru lebih kuat bila memiliki efikasi diri tinggi
\end{abstract}

Nur El-Islam, Volume 6, Nomor 2, Oktober 2019 
dari pada yang memiliki efikasi diri rendah. 5) Terdapat pengaruh interaksi antara efikasi diri dan gender equality terhadap motivasi.

Keywords: Efikasi Diri, Gender Equality, Motivasi, Ex Post Facto.

\section{A. Pendahuluan}

\section{Latar Belakang Masalah}

Landasan filosofis pendidikan Indonesia telah diuraikan secara jelas dalam (Bab I, Pasal 1, UU. SISDIKNAS No. 20 Th. 2003) yang menjelaskan bahwa: Pendidikan usaha sadar dan terencana untuk mewujudkan suasana belajar dan proses pembelajaran agar peserta didik dapat secara aktif mengembangkan potensi dirinya untuk memiliki kekuatan spiritual keagamaan, pengendilian diri, dan kepriadian, kecerdasan, akhlak mulia, serta ketrampilan yang diperluk an dirinya, masyarakat, bangsa dan Negara.ini mengisyaratkan bahwa pendidikan memiliki peran strategis yang mempunyai tanggung jawab memprsiapkan manusia Indonesia yang berkualitas.

Keberlangsungan proses kegiatan pendidikan terutama di sekolah ditentukan oleh seberapa jauh tanggung jawab guru terhadap profesinya. Guru memiliki tugas dan tanggung jawab yang beragam dan dimplementasikan dalam bentuk pengabdian. Guru adalah pendidik profesioanl dengan tuga utama mendidik, mengajar, membimbing, mengarhkan, melatih, menilai dan mengevaluasi peserta didik. Hal ini sejalan UU No, 14 Tahun 2005 tentang Guru dan Dosen (Pasal 1 ayat 1) juga dijelaskan: guru adalah pendidik professional dengan tugas utama mendidik, mengajar dan membimbing, mengarahkan melatih, menilai dan mengevaluasi peserta didik, pada anak usia dini, jalur pendidikan formal, pendidikan dasar dan pendidikan menengah.

Motivasi merupakan salah satu faktor keberhasilan guru dalam mendidik siswa. Motivasi disebabkan oleh adanya keinginan pemenuhan kebutuhan dari setiap manusia dalam bekerja, Setiap manusia tentu mempunyai dasar alasan, mengapa seseorang bersedia melakukan jenis kegiatan atau pekerjaan tertentu, mengapa orang yang satu bekerja lebih giat, sedangkan orang yang satunya lagi bekerja biasa saja, tentulah semuanya ada dasar alasan yang 
mendorong atau yang menyebabkan seseorang bersedia bekerja seperti itu atau dengan kata lain pasti ada motivasinya, termasuk juga guru dalam melaksanakan pekerjaannya. Teori motivasi mempelajari mengenai apa yang memotivasi seseorang dalam bekerja. Motivasi adalah sesuatu yang menimbulkan semangat atau dorongan kerja. Kuat lemahnya motivasi kerja seseorang menentukan tinggi rendahnya tingkat kinerja guru.

Namun kenyataan yang diperoleh gambaran bahwa motivasi guru di Kabupaten OKU Timur Kota Palembang Sum-Sel masih belum sesuai dengan harapan. Hal ini diketahui dari upaya peninggkatan kerja guru seperti peningkatan kualitas kerja, semangat kerja, daya juang dalam menyelesaikan pekerjaan masih belum optimal. Belum optimalnya upaya tersebut dapat dijadikan gambaran adanya respon guru yang terwujud dalam bentuk motivasi seseorang membutuhkan efikasi diri, terutama untuk mendorong penyelesaian tugas atau pekerjaan dengan cepat dan berkualitas.

Penurunan motivasi ini juga disebabkan oleh masih rendahnya kompensasi (gaji dan upah) yang diterima karyawan bila dibandingkan dengan tingkat pengabdian dan pengorbanan yang diberikan maupun masa kerja yang dimiliki masing-masing guru. Hal ini sejalan dengan pernyataan Ahmad Tarmizi dalam koran Palembang (sriwijaya pos) Penurunan layanan kualitas di sekolah ini sangat mungkin terjadi mengingat masih banyaknya guru yang belum terjamin kesejahteraannya, apalagi dengan kebijakan sekolah gratis, guru-guru tidak lagi dimungkinkan menerima insentif khusus dari masyarakat.

Motivasi akan mempengaruhi sikap dan perilaku individu dalam bekerja, motivasi penting karena dengan motivasi diharapkan setiap individu bekerja keras dan antusias untuk mencapai hasil kerja yang tinggi. Motivasi secara umum dapat diidentifikasikan sebagai serangkaian kekuatan penggerak yang muncul dari dalam dan diluar diri masing-masing individu. Kedua kekuatan itu menimbulkan minat kerja dan berhubungan dengan tingkah laku dan menentukan arah, intensitas dari tingkah laku atau kebiasaan individual.

Motivasi guru didukung oleh adanya keyakinan diri akan kemampuan diri dalam menjalankan pekerjaannya. Keyakinan 
individu mengenai kemampuannya dalam menjalankan tugas tertentu dikenal dengan istilah efikasi diri. Efikasi diri seseorang menentukan seberapa besar usaha dan motivasi seseorang dalam bekerja dan menyelesaikan tugasnya. Mereka yang memiliki kepercayaan diri yang kuat pada kemampuan diri akan berusaha lebih keras dan lebih termotivasi bekerja ketika menghadapi kesulitan. Hal ini juga menyangkut efikasi diri indivdu dalam pencapaian kariernya. Disamping itu gender equality (kesetaraan gender) sangat diperlukan agar guru pria dan wanita merasa tidak dibeda-bedakan, dan menikmati status yang setara dan memiliki kondisi yang sama untuk mewujudkan secara penuh hak-hak asasi dan potensi bagi pembangunan di segala bidang kehidupan hal ini dapat menumbuhkan efikasi diri dan ke percayaan diri dan dapat juga meningkatkan motivasi.

Dengan adanya efikasi diri dan gender equality diharapkan dapat memotivasi guru untuk lebih meningkatkan kinerjanya, sehingga tujuan pendidikan di Indonesia dapat tercapai sesuai harapan.

\section{Identifikasi Masalah}

Berdasarkan latar belakang masalah maka dapat diidentifikasi berbagai masalah sebagai berikut: peran motivasi guru SMA swasta di Kabupaten OKU Timur Kota Palembang Sum-Sel dalam meningkatkan hasil belajar siswa, gambaran motivasi guru SMA swasta di Kabupaten OKU Timur Kota Palembang Sum-Sel. Pengaruh efikasi diri terhadap motivasi guru SMA swasta di SMA swasta di Kabupaten OKU Timur Kota Palembang Sum-Sel, peranan efikasi diri dalam meningkatkan motivasi guru, peran gender equality (kesetaraan gender) dalam meningkatkan motivasi guru, pengaruh gender equality terhadap motivasi bila mereka memiliki efikasi diri yang berbeda dan pengaruh antara gender equality dan efikasi diri terhadap motivasi guru.

\section{Kajian Teori}

a. Motivasi

Motivasi merupakan kekuatan yang mendorong seseorang yang menimbulkan dan mengarahkan perilaku. James L. Gibson, Ivancevich, 
Donnelly dan R. Konopaske berpendapat bahwa, "motivation Is the concept we use when we describe the forces acting on or within an individual to initiate and direct behavior." ${ }^{1}$ Motivasi adalah alat pendorong yang menyebabkan seseorang merasa terpanggil dengan segala senang hati un tuk melakukan suatu kegiatan. Menurut Gibson et. al, motivasi merupakan dorongan dari dalam diri karyawan untuk melakukan pekerjaan dengan inisiatif sendiri tanpa paksaan dari orang lain.

Selanjutnya Schermerhorn dan kawan-kawan mendefenisikan motivasi, "motivation was defined as forces that account for the level and persistence of an individual's effort expended at work". ${ }^{2}$ Motivasi didefenisikan sebagai kekuatan yang menimbulkan tingkat dan ketekunan dari suatu usaha individu yang dihasilkan di tempat kerja.

Menurut Colquitt dan kawan-kawan, "motivation is defined as a set of energetic forces that originates both within and outside an employee, initiates work-related effort, and determines its direction, intensity, and persistence". ${ }^{3}$ Motivasi dapat didefenisikan sebagai seperangkat kekuatan energik yang berasal baik di dalam dan di luar karyawan, yang menunjukkan usaha yang berhubungan dengan pekerjaan, dan menentukan arah, intensitas, dan ketekunannya.

Stephen P. Robbins dan Timothy A. Judge mengatakan bahwa "motivation as the processes that account for an individual's intensity, direction, and persistence of effort toward attaining a goal."4 Motivasi sebagai proses yang mempengaruhi arah, kegigihan dan ketekunan yang dilakukan seseorang untuk mencapai tujuan.

Dari pernyataan Colquitt dan Robbins et. al, di atas dapat dipahami bahwa motivasi merupakan kekuatan baik yang datang dari

${ }^{1}$ James L. Gibson, Ivancevich, Donnelly, dan R. Konopaske, Organization Behavior, Structure, Processes (New York: McGraw-Hill, 2012), h. 126.

${ }^{2}$ John Schermerhorn, et. al., Organizational Behavior (New York: John Wiley \& Sons, Inc., 2011), h. 130.

${ }^{3}$ Jason A. Colquitt, Jeffery A. Lepine and Michael J. Wesson, Organizational Behavior: Improving Performance and Commitment in the Workplace (New York: McGrawHill Compaines, Inc, 2009), h. 179.

4 Stephen P. Robbins \& Timothy A. Judge, Organizational Behavior (New Jersey: Prentice-Hall, 2009), h. 202. 
dalam dan dari luar individu sebagai upaya dan tanggung jawabnya pegawai untuk menentukan arah atau tujuan yang ingin dicapai secara terus-menerus. Perbedaannya bahwa Colquitt mengatakan bahwa motivasi menentukan arah secara terus-menrus, sedangkan Robbins and Judge mengatakan bahwa motivasi merupakan arah, keinginan, dan ketekunan yang dilakukan seseorang untuk mencapai tujuan.

Berdasarkan uraian di atas dapat disintesiskan bahwa motivasi adalah keinginan seseorang untuk berhasil, maju, dan sukses dalam bekerja yang didasarkan pada dimensi-dimensi intensity (intensitas), direction (arah), persistence (ketekunan) dari perilaku individu dalam melakukan aktifitas untuk pencapaian tujuan organisasi.

\section{Efikasi Diri}

Kinicki dan kreitner mengemukakan defenisi efikasi diri, "self efficacy is a person's belief about his or her chance of successfully accomplishing a specific task". ${ }^{5}$ Menurut mereka efikasi diri merupakan keyakinan seseorang mengenai peluangnya untuk berhasil menyelesaikan tugas tertentu. Artinya orang yang memiliki efikasi diri akan jeli melihat peluang demi keberhasilan penyelesaian tugas. Kejelian melihat peluang ini mengindikasikan kesediaan individu yang memiliki efikasi diri tinggi untuk menerima tantangan dan menanggung resiko.

Selanjutnya Colquitt, Le Pane dan Wesson menyatakan bahwa, "self efficacy defined as the belief that a person has the capabilities needed to execute the behaviors required for task success". " Efikasi diri didefenisikan sebagai kepercayaan bahwa seseorang memiliki kemampuan yang dibutuhkan untuk melaksanakan perilaku yang dibutuhkan untuk kesuksesan tugas.

Efikasi diri menurut Schermerhorn dan kawan-kawan adalah sebagai berikut, "self efficacy is a person's belief that he or she can perfom

${ }^{5}$ Knicki Angelo and Robert Kreitner, Organizational Behavior, Key Concepts, Skills \& Best Prcatices Third Edition (New York: McGraw-Hill Companies, Inc., 2008), h. 128.

${ }^{6}$ Colquitt, Le Pene dan Wesson, Organizational Behavior. Improving Performance and Commitment in the Workplace second edition. (New York: McGraw-Hill, 2011), h. 180. 
adequately in a situation “. ${ }^{7}$ Efikasi diri adalah keyakinan seseorang bahwa ia dapat melakukan sesuatu secara memadai dalam sebuah situasi.

Efikasi diri menurut McShane, "self efficacy refers to a pearson's belief that he or has the ability, motivation, correct role perceptions, and favorable situation to complete task successfully". Efikasi diri mengacu pada keyakinan seseorang bahwa ia memiliki kemampuan, motivasi, persepsi yang benar, dan situasi yang menguntungkan untuk menyelesaikan tugas dengan sukses. Menurut McShane dan Marry Ann Glinow, mereka percaya bahwa mereka memiliki energy (motivasi), sumber daya (factor-faktor situasional), pemahaman yang benar dari program tindakan (persepsi peran), dan kompetensi (kemampuan) untuk melakukan tugas.

Berdasarkan deskripsi konsep tentang efikasi diri, dapat disintesiskan efikasi diri adalah keyakinan diri seorang individu mampu melakukan suatu pekerjaan atau tugas dengan berhasil.

\section{Gender Equality}

Gender equality (kesetaraan gender) kondisi perempuan dan lakilaki menikmati status yang setara dan memiliki kondisi yang sama untuk mewujudkan secara penuh hak-hak asasi dan potensi bagi pembangunan di segala bidang kehidupan. Gender equality (kesetaraan gender) merupakan bentuk kemitrasejajaran antara laki-laki dan perempuan dalam kehidupan keluarga, masyarakat berbangsa, dan bernegara. Berbagai peran yang dikonstruksi oleh sosial budaya masyarakat seharusnya terlepas dari tindakan diskriminasi. Sehingga laki-laki dan perempuan memiliki peluang dan kesempatan yang sama dalam mengapresiasi kewajiban dan haknya. Kewajiban dan hak merupakan sesuatu yang erat melekat dengan potensi yang dimilki oleh individu. Dengan wawasan gender maka kesetaraan laki-laki dan

${ }^{7}$ Schermerhorn, et. al., Organizational Behavior $11^{\text {th }}$ Edition (Hoboken: Jhon Wiley \& Sons, 2010), h. 332.

${ }^{8}$ McShane, Steven L. and Marry Ann Von Glinow, Organizational Behavior Emerging Knowledge and Practice for the Real Word Fith Edition. (New York: McGraw-Hill, 2010), h. 45. 
perempuan dalam seluruh aspek kehidupan adalah sebagai bentuk perwujudan hak manusia sebagai makhluk sosial dan budaya.

Manurut Noland "gender is a cultural construction which includes biological sex (male or female), psychological characteristics (femininity, masculinity, androgynous), attitudes about the sexes, and sexual orientation". ${ }^{9}$ Gender merupakan konstruksi budaya yang meliputi jenis kelamin biologis (pria atau wanita), karakteristik psikologis (feminitas, maskulinitas, androgini), sikap tentang jenis kelamin, dan orientasi seksual.

Perbedaan biologis antara laki-laki dan perempuan turut mempengaruhi cara berhubungan dan berinteraksi dalam masyarakat. Karena dalam masyarakat berbagai akumulasi peran individu bertemu. Uraian teori gender berkenaan dengan efek perbedaan biologis terhadap peran dan fungsi individu dalam masyarakat.

Javier Santiso menjelaskan pengertian gender equality (kesetaraan gender) sebagai berikut:

"Gender equality is a fundamental human right as well as a key driver for economic growth. It is therefore considered a priority on the development agenda. While there has been significant progress towards achieving gender equality, across the world many women continue to face discrimination with regard to decent employment, access to credit, property or land; their civil liberties are still limited in some parts of the world and they are often victims of violence in times of both war and peace". ${ }^{10}$

Gender equality (kesetaraan gender) adalah manusia yang mendasar yang memiliki HAM serta pendorong utama bagi pertumbuhan ekonomi. Oleh karena itu dianggap sebagai prioritas dalam agenda pembangunan. Meskipun telah ada kemajuan yang signifikan dalam pencapaian kesetaraan gender, di seluruh dunia banyak perempuan terus menghadapi diskriminasi dalam hal

${ }^{9}$ Carey M. Noland, Sex Talk: The Role Of Communication In Intimate Relationships (USA: Library of Congress Cataloging, 2010), h. 47.

${ }^{10}$ Javier Santiso, Atlas of Gender and Development: How Social Norms Affect Gender Equality In Non-Oecd Countries (Francis, OECD, 2011), h. 4. 
pekerjaan yang layak, akses terhadap kredit, properti atau tanah; kebebasan sipil mereka masih terbatas di beberapa bagian dunia dan mereka sering menjadi korban kekerasan di masa perang dan damai.

Organisation For Economic Co-Operation And Development menjelaskan bahwa:

"Gender equality as a goal of development and development assistance efforts aims to achieve equality of benefit, resources and opportunity between women and men in aid recipient countries. Gender disparities may be addressed by, a) Mainstreaming gender equality into all development cooperation efforts and or, b) Be positive actions to promote gender equality incorporating women bin development activities". ${ }^{11}$

Gender equality (kesetaraan gender) sebagai tujuan pembangunan dan pengembangan usaha bantuan bertujuan untuk mencapai kesetaraan, sumber daya dan peluang antara perempuan dan laki-laki. Kesenjangan gender dapat diatasi dengan, a) kesetaraan Pengarusutamaan gender ke dalam semua upaya kerja sama pembangunan dan atau, b) Jadilah tindakan positif untuk mempromosikan kesetaraan gender menggabungkan perempuan dalam kegiatan pembangunan.

Gender equality (kesetaraan gender) adalah tidak adanya diskriminasi berdasarkan jenis kelamin seseorang dalam memperoleh kesempatan dan alokasi sumber daya, manfaat atau dalam mengakses pelayanan.

Robert B. Zoellick, menjelaskan pula tentang gender equality: Gender equality is a core development objective in its own right. It is also smart economics. Greater gender equality can enhance productivity, improve development outcomes for the next generation, and make institutions more representative. ${ }^{12}$

${ }^{11}$ Organisation For Economic Co-Operation And Development, Creditor Reporting System Aid Activities in Support of Gender Equality (New York: 2005), h. 10.

${ }^{12}$ Robert B. Zoellick, Gender Equality And Development (Washington: World Bank, 2012), h. 10. 
Kesetaraan gender merupakan tujuan pembangunan utama dalam dirinya sendiri. Kesetaraan gender yang lebih besar dapat meningkatkan produktivitas, meningkatkan hasil pembangunan untuk generasi berikutnya, dan membuat lembaga yang lebih representatif.

Berdasarkan deskripsi konsep tentang gender equality (kesetaraan gender), dapat disintesiskan gender equality berarti kesamaan kondisi bagi laki-laki dan perempuan untuk memperoleh kesempatan serta hak-haknya sebagai manusia, agar mampu berperan dan berpartisipasi dalam bidang pendidikan kegiatan politik, hukum, ekonomi, sosial budaya, serta kesamaan dalam menikmati hasil pembangunan tersebut.

\section{Tujuan Penelitian}

Penelitian ini bertujuan untuk mengungkapkan/menguji bahwa

1. Mengetahui perbedaan motivasi guru SMA Swasta Kabupaten OKU Timur Kota Palembang Sum-Sel akibat perbedaan Efikasi diri yang mereka miliki.

2. Mengetahui perbedaan motivasi guru SMA Swasta Kabupaten OKU Timur Kota Palembang Sum-Sel akibat perbedan Gender yang mereka miliki.

3. Untuk mengetahui perbedaan motivasi guru pria apakah motivasinya berbeda bila mereka memiliki efikasi diri tinggi atau dengan guru yang memiliki efikasi diri rendah.

4. Untuk mengetahui guru wanita apakah motivasinya lebih kuat bila mereka memiliki efikasi diri tinggi atau dengan guru yang memiliki efikasi diri rendah.

5. Mengetahui perbedaan motivasi guru SMA Swasta Kabupaten OKU Timur Kota Palembang Sum-Sel interaksi antara efikasi diri dan perbedaan gender yang mereka miliki

\section{B. Metodologi Penelitian}

1. Metodologi Penelitian

Metode yang digunakan dalam penelitian ini adalah penelitian komparatif atau perbandingan. Metode penelitian komparatif adalah bersifat ex post facto, artinya data dikumpulkan setelah semua kejadian 
yang dikumpulkan telah selesai berlangsung. Penelitian tersebut tidak mempunyai control terhadap variable bebas, karena penelitian komparatif sifatnya ex post facto. Penelitian komparatif adalah sejenis penelitian deskriptif yang ingin mencari jawaban secara mendasar tentang sebab akibat, dengan menganalisis faktor-faktor penyebab terjadi ataupun munculnya suatu fenomena tertentu. Dalam studi komparatif ini, memang sangat sulit untuk mengetahui faktor-faktor yang dijadikan dasar pembanding, sebab penelitian komparatif tidak mempunyai kontrol. Penelitian dilaksanakan di SMA Swasta Kabupaten OKU Timur Kota Palembang Sum-Sel. Adapun teknik pengambilan sampel dalam penelitian ini yaitu menggunakan teknik acak sederhana (simple random sampling). Untuk jumlah responden relatif banyak (sekitar 150), dapat digunakan angka 30\%, 27\%, 25\%. Ukuran terbaik dalam memilih kelompok tinggi dan kelompok rendah adalah 27\% dari populasi. Langkah-langkah yang diambil dalam pengambilan sampel yang pertama adalah dengan mencari sampel pada guru SMA Swasta di Kabupaten OKU Timur Kota Palembang Sum-Sel. Sampel yang diambil diyakini telah representatif untuk selanjutnya diambil datanya. Kemudian diberikan instrument penelitian dan selanjutnya data yang dihasilkan diolah.

\section{Hipotesis Penelitian}

1. Secara keseluruhan, motivasi guru berbeda bila memiliki efikasi diri tinggi dengan guru yang memiliki efikasi diri rendah

2. Secara keseluruhan, motivasi guru berbeda antara guru pria dan guru wanita.

3. Bagi guru pria, motivasi guru berbeda antara yang memiliki efikasi diri tinggi dengan yang memiliki efikasi diri rendah

4. Bagi guru wanita, motivasi guru lebih kuat bila memiliki efikasi diri tinggi dari pada efikasi diri rendah

5. Terdapat pengaruh interaksi antara efikasi diri, dan gender equality terhadap motivasi.

Berdasarkan hipotesis penelitian di atas dapat digambarkan sebagai berikut: 


\begin{tabular}{|c|c|c|c|}
\hline & & \multicolumn{2}{|c|}{ Efikasi Diri (A) } \\
\hline & & Tinggi (A1) & Rendah (A2) \\
\hline \multirow{2}{*}{$\begin{array}{l}\text { Gender } \\
\text { Equaity } \\
\text { (B) }\end{array}$} & $\begin{array}{l}\text { Pria } \\
\text { (B1) }\end{array}$ & A1B1 & A2B1 \\
\hline & $\begin{array}{c}\text { Wanita } \\
\text { (B2) }\end{array}$ & A1B2 & A2B2 \\
\hline
\end{tabular}

Gambar: Hipotesis Penelitian

C. Hasil dan Pembahasan

1. Secara Keseluruhan, Terdapat Perbedaan Motivasi Guru yang Memiliki Efikasi Diri Tinggi dengan Efikasi Diri Rendah

Berdasarkan hasil analisis varian (ANAVA) pada taraf signifikan $\alpha$ $=0,01$, didapat $F_{\text {hitung }}=12,139$ dan $F_{\text {tabel }}=6,967$. Rangkumannya dapat dilihat pada tabel 4.11 dan perhitungannya dapat dilihat pada lampiran. Dengan demikian $\mathrm{F}_{\text {hitung }}>\mathrm{F}_{\text {tabel}}$, sehingga $\mathrm{H}_{\mathrm{o}}$ ditolak, dapat disimpulkan bahwa secara keseluruhan, terdapat perbedaan yang nyata antara motivasi guru yang memiliki efikasi diri tinggi dengan efikasi diri rendah. Dengan perkataan lain bahwa motivasi guru yang memiliki efikasi diri tinggi berbeda dengan motivasi guru yang memiliki efikasi diri rendah. Efikasi diri yang tinggi akan meninggikan motivasi guru. Pernyataan ini diperkuat oleh Gibson dan kawankawan, "a person high in self efficacy is more motivated to perform at high levels of achievement." Seseorang memiliki efikasi diri tinggi, lebih termotivasi untuk menghasilkan kinerja yang lebih baik. Ini berarti hipotesis penelitian yang menyatakan bahwa secara keseluruhan motivasi guru yang memiliki efikasi diri tinggi dengan motivasi guru yang memiliki efikasi diri rendah ada perbedaan yang sigifikan terbukti dalam hasil penelitian ini. 
2. Secara Keseluruhan, Motivasi Guru Berbeda antara Guru Pria dan Guru Wanita

Hasil pengujian hipotesis kedua berdasarkan hasil analisis varian (ANAVA) pada taraf signifikan $\alpha=0,001$, didapat $F_{\text {hitung }}=12,139$ dan $\mathrm{F}_{\text {tabel }}=11,683$, berdasarkan hasil ini $\mathrm{H}_{\mathrm{o}}$ ditolak $\mathrm{H}_{1}$ diterima. Secara keseluruhan menjelaskan adanya pengaruh yang berarti antara motivasi guru antara kelompok pada guru pria dan guru wanita. Temuan dalam penelitian ini menunjukan bahwa secara keseluruhan kelompok pada guru pria memiliki motivasi yang berbeda dengan kelompok guru wanita. Hal ini dapat disebabkan karena Pengamatan perbedaan motivasi gender didasarkan pada gagasan perbedaan antara pria dan wanita, yaitu pada keberadaan stereotipe gender, yang dapat ditelusuri kembali ke konteks historis pria dari persepsi prioritas berdasarkan perbedaan jenis kelamin.

Tamila Arnania-Kepuladze juga berpendapat (2010:5) "motivation and gender differences. Gender stereotypes adherents consider that on work place men and women are also taking various preferences, goals and are motivated in a different way. The satisfaction of stereotypical masculine needs such as economic success, autonomy and achievement is more typical for men. Hence, for men earnings, freedom, advancement, challenge, possibility to use skills etc. are more significant performance motivators. According to gender stereotypical model, women should fulfill family needs and care of the quality of their family life. So, for women interpersonal relationship, security, fringe benefits, environment etc. should be more important".

Motivasi dan perbedaan jenis kelamin, bahwa pria dan wanita juga mengambil berbagai peluang/keinginan, tujuan di tempat kerja mereka oleh karena itu memiliki motivasi yang berbeda. Untuk lakilaki motivasinya dalam bekerja yaitu untuk pemenuhan kebutuhan seperti keberhasilan ekonomi, otonomi dan prestasi. Oleh karena itu, untuk itu pria lebih termotivasi untuk pendapatan hasil kerja, kebebasan, kemajuan, lebih menyukai tantangan. Menurut jenis kelamin perempuan motivasinya yaitu untuk memenuhi kebutuhan keluarga dan untuk memenuhi kualitas hidup keluarga mereka. Jadi, bagi wanita hubungan interpersonal, keamanan, tunjangan, 
lingkungan dan lain-lain harus lebih penting. Ini berarti hipotesis penelitian yang menyatakan bahwa secara keseluruhan motivasi guru yang memiliki gender equality pada pria dan wanita ada perbedaan yang sigifikan terbukti dalam hasil penelitian ini.

\section{Bagi Guru Pria Memiliki Motivasi Berbeda antara Guru yang Memiliki Efikasi Diri Tinggi dengan Guru Yang Memiliki Efikasi Diri Rendah.}

Hasil penelitian pada hipotesis ketiga, Berdasarkan hasil pengujian dengan uji Tuckey terhadap motivasi pada motivasi pada kelompok guru yang memiliki efikasi diri tinggi pada guru pria $\left(\mathrm{A}_{1} \mathrm{~B}_{1}\right)$ dibanding dengan kelompok guru yang memiliki efikasi diri rendah $\left(A_{2} B_{1}\right)$, diperoleh $q_{\text {hitung }}=11,31$ dan $q_{\text {tabel }}=3,96$. Dengan demikian $q_{\text {hitung }}$ lebih besar daripada $\mathrm{q}_{\text {tabel}}$, sehingga $\mathrm{H}_{\mathrm{o}}$ ditolak $\mathrm{H}_{1}$ diterima, sehingga dapat disimpulkan bahwa ada perbedaan motivasi pada kelompok guru pria yang memiliki efikasi diri tinggi dengan motivasi pada kelompok guru pria yang memiliki efikasi diri rendah. Dengan demikian hipotesis penelitian yang menyatakan bahwa pada guru pria memiliki motivasinya berbeda antara guru pria yang memiliki efikasi diri tinggi dengan pada guru pria yang memiliki efikasi rendah terbukti dalam penelitian ini.

Hasil temuan ini sesuai dengan pendapat yang dikemukakan oleh Menurut Stephen Robbins (2011: 190) "self efficacy refers to individuals belief that he or she is capable of performing performing a task, the higher your self efficacy, the more confidence you have in your ability to succeed. So, in difficult situasions, people with low self efficacy are more likely so lessen their effort or give ip attogether, while those with high self efficacy will tryharder to master the challenge. In addition, individuals high in self efficacy seem to respond to negative feedback with increased effort and motivation, whil those low in self efficacy are likely to lesson their effort when given negative feedback".

Maksud dari pendapat Stephen Robbins (2011:190) di atas efikasi diri mengacu pada keyakinan individu (laki-laki dan perempuan) bahwa dia mampu melakukan pekerjaan. Efikasi diri yang tinggi dapat membuat seseorang meraih sukses. Jadi dalam situasi sulit, orang 
dengan rendah efikasi diri lebih mungkin sehingga mengurangi usaha mereka atau menyerah sama sekali, sementara mereka dengan efikasi diri yang tinggi akan berusaha lebih keras untuk menguasai tantangan. Selain itu efikasi diri yang tinggi dapat menanggapi umpan balik negatif dengan peningkatan usaha dan motivasi. Sedangkan efikasi diri yang rendah akan cenderung mengurangi usaha mereka ketika diberi umpan balik negatif. Dapat disimpulkan bahwa terdapat perbedaan motivasi guru antara guru yang memiliki efikasi diri tinggi dengan guru yang memiliki efikasi diri rendah.

\section{Bagi Guru Wanita Motivasi Guru Lebih Kuat Bila Memiliki Efikasi Diri Tinggi}

Hasil penelitian pada hipotesis keempat: berdasarkan hasil pengujian dengan uji Tuckey terhadap motivasi guru yang memiliki efikasi diri tinggi pada guru wanita $\left(\mathrm{A}_{1} \mathrm{~B}_{2}\right)$ dibanding dengan motivasi guru yang memiliki efikasi diri rendah pada guru wanita $\left(\mathrm{A}_{2} \mathrm{~B}_{2}\right)$, diperoleh $\mathrm{q}_{\text {hitung }}=6,257$ dan $\mathrm{q}_{\text {tabel }}=3,960$. Dengan demikian $\mathrm{q}_{\text {hitung }}$ lebih besar daripada $\mathrm{q}_{\text {tabel}}$, sehingga Ho ditolak, sehingga dapat disimpulkan bahwa pada guru wanita memiliki motivasi yang lebih kuat bila mereka memiliki efikasi diri tinggi. Dengan demikian hipotesis penelitian yang menyatakan bahwa pada guru wanita memiliki motivasinya lebih tinggi bila mereka memiliki efikasi diri tinggi dibandingkan dengan pada guru wanita yang memiliki efikasi diri rendah terbukti dalam penelitian ini. Dengan perkataan lain bahwa motivasi guru yang memiliki efikasi diri tinggi pada guru wanita tidak lebih tinggi secara signifikan dari pada dengan motivasi guru yang memiliki efikasi diri rendah pada guru wanita. Dengan demikian pada guru wanita dengan efikasi diri tinggi memiliki motivasi yang tidak iebih kuat dibandingkan dengan pada guru wanita dengan efikasi diri rendah.

Menurut Bandura (1986: 115) "women employees who have a low sense of efficacy are stressed by heavy work demands and role responsibilities. By Contrast, those with a high sense of efficacy by limited opportunities to make full use of their talents". Guru perempuan yang memiliki efikasi diri rendah akan tertekan oleh tututan kerja dan 
tanggung jawab yang berat. tapi sebaliknya perempuan yang memiliki efikasi diri tinggi akan memanfaatkan kesempatan untuk menggunakan bakat mereka. Maksudnya adalah perempuan yang memiliki efikasi diri tinggi akan memiliki motivasi yang tinggi pula untuk melakukan suatu pekerjaan atau tugas dengan berhasil. Dengan demikian pada guru wanita dengan efikasi diri tinggi memiliki motivasi yang tidak lebih kuat dibandingkan dengan pada guru wanita dengan efikasi diri rendah.

\section{Interaksi Antara efikasi diri dengan gender equality}

Berdasarkan hasil analisis varian tentang interaksi antara efikasi diri dan gender equality terhadap motivasi terlihat pada table perhitungan Anava di atas, bahwa harga hitung Fhitung interaksi = 47,142 dan Ftabel $=6,967$ pada $\alpha=0,01$. Tampak bahwa Fhitung $>$ Ftabel, sehingga Ho ditolak. Kesimpulannya bahwa terdapat interaksi antara efikasi diri dengan gender equality.

Hal ini diperkuat oleh pendapat Menurut Stephen Robbins(2009:180) "self efficacy refers to individuals belief that he or she is capable of performing performing a task, the higher your self efficacy, the more confidence you have in your ability to succeed. So, in difficult situasions, people with low self efficacy are more likely so lessen their effort or give ip attogether, while those with high self efficacy will tryharder to master the challenge. In addition, individuals high in self efficacy seem to respond to negative feedback with increased effort and motivation, whil those low in self efficacy are likely to lesson their effort when given negative feedback". Dari pendapat Stephen Robbins dapat disimpulkan efikasi diri mengacu pada keyakinan individu (laki-laki dan perempuan) bahwa dia mampu melakukan pekerjaan. Efikasi diri yang tinggi dapat membuat seseorang meraih sukses. Jadi dalam situasi sulit, orang dengan rendah efikasi diri lebih mungkin sehingga mengurangi usaha mereka atau menyerah sama sekali, sementara mereka dengan efikasi diri yang tinggi akan berusaha lebih keras untuk menguasai tantangan. Selain itu efikasi diri yang tinggi dapat menanggapi umpan balik negatif dengan peningkatan usaha dan motivasi. Sedangkan efikasi diri yang rendah akan cenderung mengurangi usaha mereka 
ketika diberi umpan balik negatif. Orang-orang baik itu laki-laki maupun perempuan memiliki efikasi diri yang tinggi akan lebih besar usahanya untuk melakukan kegiatan-kegiatan guna mencapai tujuan atau kebutuhan sesuai harapan. Menurut Bandura "the different forms of social influence affects four major aspects of gender-role development and functioning. these include outcome expectations concerning gendered conduct and roles, self-evaluative standards, and self-efficacy beliefs". ${ }^{13}$ Berbagai bentuk pengaruh sosial mempengaruhi aspek utama pembangunan peran dan fungsi gender. ini mempengaruhi perilaku dan peran gender, standar evaluatif diri, dan keyakinan efikasi diri.

Bandura juga berpendapat "Perceived self-efficacy refers to beliefs in one's capabilities to organize and execute the courses of action required to manage perspective situations. beliefs influence how people think, feel, motivate themselves, and act". ${ }^{14}$ Efikasi diri mengacu pada keyakinan dalam kemampuan seseorang untuk mengatur dan mengambil arah tindakan yang diperlukan untuk mengatur sudut pandang keadaan. Efikasi diri memengaruhi keyakinan seseorang dalam berpikir, merasa, memotivasi diri, dan bertindak.

Sebagai ekspresi dari keyakinan seorang individu baik itu lakilaki atau perempuan (gender) dalam melaksanakan tugas tertentu, efikasi diri sangat dibutuhkan oleh seorang guru baik itu guru laki-laki atau perempuan untuk membangkitkan motivasi untuk memenuhi tujuan pribadi dan sekolah tercermin dalam realisasi keyakinan diri akan kemampuan dalam bekerja keyakinan diri untuk mengatasi rintangan, keyakinan diri untuk berhasil, keyakinan diri untuk bersaing, keyakinan diri untuk menerima tantangan, keyakinan diri untuk menanggung resiko. Dengan demikian maka terdapat pengaruh interaksi antara efikasi diri, dan gender equality terhadap motivasi.

${ }^{13}$ Bandura, Self-efficacy in Changing . h. 16.

${ }^{14}$ Ibid. h. 2. 


\section{Kesimpulan}

Berdasarkan hasil analisa dan kajian dari penelitian ini dapat disimpulkan bahwa:

a. Secara keseluruhan motivasi guru berbeda bila memiliki efikasi diri tinggi dengan guru yang memiliki efikasi diri rendah.

b. Secara keseluruhan motivasi guru berbeda antara guru pria dan guru wanita.

c. Bagi guru pria motivasinya berbeda antara yang memiliki efikasi diri tinggi dengan yang memiliki efikasi diri rendah.

d. Bagi guru wanita motivasinya lebih kuat bila memiliki efikasi diri tinggi.

e. Terdapat pengaruh interaksi antara efikasi diri, dan gender equality terhadap motivasi.

\section{Daftar Pustaka}

Albert Bandura, Self-efficacy in Changing Society. (New Jersey: Preenpice Hall, 1986)

Jason A Colquitt. Jeffery A. LePine dan Michael J. Wesson, Organizational Behavior. Improving Performance and Commitment in the Workplace second edition. New York: McGraw-Hill, 2011.

James L Gibson, Organizations: Behavior, Structure, Processes, Fourteenth Edition, (New York: McGraw-Hill Companies, Inc., 2012)

Fred Luthan. Organizational Behavior. New York: McGraw-Hill, 2011.

Steven L McShane. dan Mary Ann Von Glinow. Organizational Behavior Emerging Knowledge and Practice for the Real Word Fith Edition. New York: McGraw-Hill, 2010.

Stephen P Robbins. dan Timothy A. Judge,Organization Behavior. New Jersey: Prentice Hall Inc, 2011.

John R Schermerhorn, et al. Organizational Behavior. Hoboken: John Wiley \& Son Inc, 2010. 
Pengaruh Efikasi Diri...

Paula Nicolson. Gender Power and Organization. A Psychological Perspektive. London and New York: Francis e-Library, 2005.

Robert B Zoellick. Gender Equality And Development, 8Washington: World Bank, 2012. 